\title{
The Spatial Distribution of Heavy Metal Lead and Cadmium Pollution and Coliform Abundance of Waters and Surface Sediment in Demak
}

\author{
Agus Tjahjono ${ }^{1 *}$, Djoko Suwarno² \\ 1 Engineering Department, Semarang Merchant Marine Polytechnic (Politeknik Ilmu Pelayaran Semarang), \\ Singosari 2 a Semarang, 50242, Central Java, Indonesia \\ 2 Civil Engineering Department, Unika Soegijapranata Chatolic University, Pawiyatan Luhur IV/1 Bendan \\ Dhuwur, Semarang, 50234, Central Java, Indonesia \\ * Corresponding author's e-mail:a_agus_tjahjono70@yahoo.co.id
}

\begin{abstract}
Various activities such as farming, industry, household waste, fish pond, and fishery can possibly affect the estuarine and coastal ecosystem. Demak waters, located to the east of Tanjung Emas Semarang, become an influential element of fishery industry that mostly produces anchovies and shrimps. This research was aimed at (1) analyzing the spatial distribution of heavy metal $\mathrm{Pb}$ and $\mathrm{Cd}$ in the surface water and sediment; and (2) investigating the abundance of coliform in Demak waters. Moreover, in this research, water pollution index was also analyzed and compared to other polluted water areas. It was found that the $\mathrm{Pb}$ content ranged from 0.6037 to $0.6647 \mathrm{mg} \cdot 1^{-1}$ whereas the $\mathrm{Cd}$ content ranged from 0.064 to $0.1707 \mathrm{mg} \cdot 1^{-1}$. Both lead and cadmium contents had surpassed the water quality standard. The $\mathrm{Pb}$ content in sediment ranged from 0.563 to $0.6823 \mathrm{mg} \cdot \mathrm{kg}^{-1}$ whereas the Cd content reached 0.0047 to $0.0577 \mathrm{mg} \cdot \mathrm{kg}^{-1}$. It showed that this sediment was not polluted by $\mathrm{Pb}$ and $\mathrm{Cd}$. The analysis of water pollution index revealed that the pollution level found in Morosari, Rejo, Tuntang, and Lohbener estuary was low. On the other hand, Wedung and Serang estuary were heavily polluted. Compared to some previous studies, most of $\mathrm{Pb}$ and $\mathrm{Cd}$ contents in Demak waters were greater. However, lead and cadmium content in sediment was lower.
\end{abstract}

Keywords: Demak waters, spatial distribution of $\mathrm{Pb}$ and $\mathrm{Cd}$ in surface water and sediment, the abundance of Coliform, water pollution index

\section{INTRODUCTION}

Demak Regency, located in Central Java, geographically, lies in the coordinates of 6 $6^{\circ} 3^{\prime} 26^{\prime \prime}$ South and $110^{\circ} 27^{\prime} 58^{\prime \prime}-110^{\circ} 48^{\prime} 47^{\prime \prime}$ East. This region extends over 89,743 ha. It borders with Jepara regency and the Java Sea to the north, Kudus and Grobogan regencies to the east, Grobogan and Semarang regencies to the south and Semarang to the west. Demak consists of 14 subdistricts. A few rivers flow through Demak, including Tuntang, Buyaran, and the biggest river in Demak, Serang [https://idwikipedia.org].

Demak waters are located to the east of Port of Tanjung Emas Semarang. It became an influential element of fishery industry, as it produces 308.556 tons of anchovies and 139.296 tons of shrimps [BPS, 2013]. However, high ecological pressure was also found in this area [Hastuti et al., 2013].

On the basis of the previous studies carried out in Moro Demak waters, it was revealed that the $\mathrm{Cd}$ content in the surface water reached 0.116 $\mathrm{mg} / \mathrm{l}$ whereas the $\mathrm{Cd}$ content in the sediment was $1.372 \mathrm{mg} / 1$. It means that it had surpassed the water quality standard. When the concentration of heavy metal $\mathrm{Pb}$ in the water and sediment increases, the accumulation of heavy metal $\mathrm{Pb}$ in Anadara granosa will be elevated as well [Sitorus, 2004]. It leads to a bioaccumulation in the blood clam Anadara granosa clam [Wulandari et al., 2009].

The coliform bacteria constitute the indicator of patogenic bacteria existence. The more coliform we found within the water, the worse the water quality would be. The coliform bacteria include various bar shaped 
bacteria, gram-negative bacteria, non-sporeforming bacteria, and lactose-fermenting bacteria which produce gas and acid when being incubated at $37^{\circ} \mathrm{C}$ in less than 48 hours [Widyaningsih et al., 2016]. The existence of these bacteria is due to pollutants produced by human activities around the river.

Heavy metals are generally defined as the metals with relatively high densities, atomic weights, or atomic numbers. Heavy metals differ from other metals due to the effect they produce when being bound to the living organism. The heavy metal $\mathrm{Pb}$ is commonly used in the industry producing batteries and cables. However, the use of water-related contamination, the metal was added as an additive to the engine fuel to increase the octane value. The heavy metal $\mathrm{Cd}$ is used as a mixture in the chemical industry [Palar, 2012; Ridhowati, 2013].

This research was aimed at analyzing the spatial distribution of $\mathrm{Pb}$ and $\mathrm{Cd}$ in the surface water and sediment, as well as the abundance of Coliform in Demak waters. This research also analyzed the water pollution index and compared the results to the previous studies on water pollution.

\section{MATERIALS AND METHODS}

\section{Research object}

The research was held in May 2017 when the high tide occured at Demak waters, Central Java, Indonesia. The purposeful sampling was done at six stations including station 1, Morosari estuary (6 $6^{\circ} 2^{\prime} 60^{\prime \prime}$ South, $110^{\circ} 46^{\prime} 07^{\prime}$ ' East), Rejo estuary (6 $6^{\circ} 85^{\prime} 20^{\prime \prime}$ South, $110^{\circ} 51^{\prime} 40^{\prime \prime}$ East), Tuntang estuary (6 $6^{\circ} 83^{\prime} 24^{\prime \prime}$ South, $110^{\circ} 51^{\prime} 76^{\prime \prime}$ East), Lohbener estuary ( $6^{\circ} 77.09^{\prime}$ 'South, $110^{\circ} 56^{\prime} 85^{\prime \prime}$ East), Wedung estuary (6⒎54' South, $110^{\circ} 53^{\prime} 24^{\prime \prime}$ East), and Serang estuary (6 $6^{\circ} 1^{\prime} 99^{\prime \prime}$ South, $110^{\circ} 54^{\prime} 37^{\prime \prime}$ East).

In each station, the sampling was done three times. The Morosari estuary was taken as the sampling location because firstly, it was mangrove area which is the fishery habitat and secondly, absorption of heavy metal possibly occurs in this area. Other estuaries were also used as the sampling locations since they were close to the fishermen settlement and fish farming.

\section{Data collection methods}

The materials of this research included the sample of sea water and sediments which contained $\mathrm{Pb}, \mathrm{Cd}$, and Coliform taken from Demak waters. In this research, primary and secondary research data were applied. The primary data included the data which were taken directly when the research took place including seawater, $\mathrm{pH}$, DO, TDS, water turbidity, water depth, salinity, current, and the water transparency.

The determination of heavy metal concentration $(\mathrm{Pb}$ and $\mathrm{Cd})$ in the seawater.

Firstly, 500 mililiters of sea water was put into teflon separatory funnel. The $\mathrm{pH}$ scale was then set at $\mathrm{pH} 4$ by adding liquid $\mathrm{HCl}$. APDC (Amonium Pirolidin Ditio Carbamat) and NaDDC (Natrium Dietil Ditio Carbamat) were also added before it was shaken for one minute. Afterwards, $25 \mathrm{ml}$ of MIBK (Metil Iso Butil Keton) was also added and the solution was shaken again for 30 seconds. The aqueous phase was then separated. Subsequently, $10 \mathrm{ml}$ of distilled and deionized water was poured into the upper phase. It was shaken and the aqueous phase was then separated. After that, $1 \mathrm{ml}$ of $\mathrm{HNO}_{3}$ was added, shaken, and left standing for about an hour. Then, $19 \mathrm{ml}$ of distilled and deionized water was added, shaken, and aqueous phase was collected to be analyzed by using furnace AAS (Atomic Absorption Spectroscopy) with argon gas and $\mathrm{Pb}$ and $\mathrm{Cd}$ lamps [Sitorus, 2004; APHA, 2012].

The sample of sediment was dried at $105^{\circ} \mathrm{C}$ for 24 hours. Then 10-20 grams of the dried sediment was put into a centrifuge tube (polyethylene), $500 \mathrm{ml}$ of distilled and deionized water was added and shaken. It was afterwards centrifuged for 30 minutes in 2000 RPM. The aqueous phase was then discarded. It was dried at $105^{\circ} \mathrm{C}$ (ovendry weight) for 24 hours. 1 gram of sediment was put into a sealed teflon beaker. Subsequently, $5 \mathrm{ml}$ of aqua regia and $6 \mathrm{ml}$ of HF (Hygrogen Fluoride) were added. It was then heated at $130{ }^{\circ} \mathrm{C}$ until it was dried up. Next, $9 \mathrm{ml}$ of distilled and deionized water was added. It was then analyzed by using furnace AAS with argon gas and $\mathrm{Pb}$ and $\mathrm{Cd}$ lamps based on the types of the metal which were being analyzed [Sitorus, 2004; APHA, 2012].

The coliform bacteria determination used MPN (Most Probable Number) method [SNI01-2332-1991; Ijong, 2015]. The method was as follows:

- Presumtive test of coliform 
The first step of the presumtive test was to prepare trisalt solution with $10^{-1}$ to $10^{-3}$ dilution and to shake until it was homogenous, and to prepare nine tubes of LTB (Lauryl Tryptose Broth) which contained Durham tube for one sample. Then, $1 \mathrm{ml}$ of sample water was added into tube $10^{-1}$ and shaken until it was homogenous by using vortex. Next, $1 \mathrm{ml}$ of the solution was taken from tube $10^{-1}$ and put into tube $10^{-2}$, and the process was continued until tube $10^{-3}$.

By using a sterile pipette, $1 \mathrm{ml}$ of solution of each dilution was moved into each of the three LTB tubes. The process was continued until the sixth sample. The tubes were then incubated at $35^{\circ} \mathrm{C}$ for about $24-48$ hours. Positive tubes would produce bubbles in the Durham tube.

\section{- Confirmative test of Coliform}

The method used in this test included moving the cultures from the positive LTB tubes to the tubes with BGLB (Briliant Green Lactose Bile) $2 \%$ broth which contained the Durham tube by using inoculation needle. The tubes were incubated for $24-48$ hours at $35^{\circ} \mathrm{C}$. The positive tubes were those which produced gas in Durham tube. The numbers of the positive tubes were compared based on the MPN value in order to find out the numbers of coliform within the sample.

\section{- Completed test}

By using a loopful, the typical colony above was moved to the lactose broth. Then, the formation of acid and gas was re-observed. When the result was positive, aseptically, one eye of loopful was taken and scratched to the NA, and subsequently incubated at $37^{\circ} \mathrm{C}$ overnight. The growing colony was then used in Gram-Coloring test. The test was regarded as positive if Gram-Negative was obtained and stem cells were formed.

\section{Data analysis}

The data analysis method used to examine the density of Coliform bacteria [SNI 2897-2008, Bambang et al., 2014] was as follows:

$$
\begin{gathered}
\text { Coliform Density }= \\
=\text { value } \text { of MPN table } \times \frac{1}{\text { Median dillution }}
\end{gathered}
$$

The data analysis of (1) the heavy metal $\mathrm{Pb}$ and $\mathrm{Cd}$ content in water and sediment, and (2) the coliform abundance was done by using a comparative analysis of temperature, $\mathrm{pH}, \mathrm{DO}, \mathrm{TDS}$, salinity, and turbidity. In this analysis, the Spearman's rank-order correlation was applied. This correlation analysis would show the correlation between two variables. The analysis employed SPSS software for Windows, version 22.

The status of water pollution was determined by using the water pollution index based on Ministry of Environment Decree No. 115 year 2003 about the guidelines for water quality assessment. [Nemerow \& Sumitomo, 1970].

$$
\mathrm{PI}_{\mathrm{j}}=\sqrt{\frac{\left(\mathrm{C}_{\mathrm{i}} / \mathrm{L}_{\mathrm{ij}}\right)_{M}^{2}+\left(\mathrm{C}_{\mathrm{i}} / \mathrm{L}_{\mathrm{ij}}\right)_{\mathrm{R}}^{2}}{2}}
$$

where: $L_{i j}$ - standard water quality parameter for each parameter at specified water quality purpose $(\mathrm{j})$

$C_{i}-$ measured water quality parameters

$P I_{j}$ - the pollution index for a specified water quality purpose $(\mathrm{j})$

$\left(C_{i} / L_{i j}\right)_{M}$ - maximum value of $C_{i} / L_{i j}$

$\left(C_{i} / L_{i j}\right)_{R}$ - average value of $C_{i} / L_{i j}$

The pollution level based on the water pollution index of water quality standard as written in Ministry of Environment Decree no. 115 year 2003 is $0 \leq \mathrm{PI}_{\mathrm{j}} \leq 1$ (meet quality standard/good), $1 \leq \mathrm{PI}_{\mathrm{j}} \leq 5$ (lightly polluted), $5 \leq \mathrm{PI}_{\mathrm{j}} \leq 10$ (moderately polluted) dan PIj $>10$ (heavily polluted).

\section{RESULTS AND DISCUSSION}

On the basis of the findings in the six stations at Demak waters, it was revealed that the $\mathrm{Pb}$ content at riverbed was higher than what was found at the surface of the water. The $\mathrm{Pb}$ content found at surface of the water ranged from 0.6037 to $0.6647 \mathrm{mg} \cdot 1^{-1}$. The highest concentration of $\mathrm{Pb}$ was found at the Serang estuary. The concentration was thirteen times higher than the water quality index $0.05 \mathrm{mg} . \mathrm{l}^{-1}$. Serang estuary is the biggest river on which the fishermen often go back and forth to the sea. The condition matched with the high concentration of TSS, which proved that a high concentration possibly decreased the photosyntesis activity of both macro and micro marine plants. It led to the decrease of the oxygen which killed fish [Jiyah et al., 2017]. On the other hand, the concentration of $\mathrm{Pb}$ in the riverbed was about 0.6207 and $0.7163 \mathrm{mg} \cdot \mathrm{l}^{-1}$; the highest concentration occurred at the estuary of Tuntang river. The concentration surpassed the minimum require- 
ment of the water quality index; it was fourteen Times higher than what was required (Figure 2).

The $\mathrm{Pb}$ within seawater was able to accumulate to the benthic. The largest accumulation was found in hard branching coral which was followed by soft coral Alcyonaceae. For example, the accumulation of Acropora aspera and Pocillopora damicornis, within ten days, turned into $0.895 \mathrm{mg} \cdot \mathrm{kg}^{-1}$ [Samawi et al., 2014; Panuntun et $a l, 2012]$. The pollution of $\mathrm{Pb}$ led to the highest accumulation in the sediment. The accumulation was followed by biota and seawater [Usman et al., 2013]. The metal accumulation additionally showed the toxic effect of $\mathrm{Pb}$ to Cromileptus altivelis. The effect of $\mathrm{Pb}$ caused the damage of hepar cell (concentration $0.15 \mathrm{ppm}$ ) in the form of fatty degeneration, hydropic degeneration, hemorrhage, congestion, and necrosis hepatica (liver cell death) [Triadayani et al., 2010]. The accumulation of $\mathrm{Pb}$ in mullet fish Mugin cephalus (Linnaeus, 1758) in Cilacap waters was three times higher than those which were taken from 0-500 $\mathrm{m}$ and $>1000 \mathrm{~m}$ from the pollution source point [Heriyanto \& Subiandono, 2011].

The content of $\mathrm{Pb}$ in the sediment possibly affected the organisms living at the riverbed, such as the Strombus canarium snail. The greater content of the heavy metal in the sediment, the higher content of $\mathrm{Pb}$ found in the organism [Nasution \& Siska, 2011]. Blood clam Anadara granosa and mangrove shell Polymesoda bengalensis were also found in the sediment. When the content of $\mathrm{Pb}$ within the sediment reached $0.823 \mathrm{mg} \cdot \mathrm{kg}^{-1}$, an accumulation of both organisms was twice higher (1.750 mg.kg ${ }^{-1}$ [Amriani et al., 2011]. Moreover, Anadara granosa was highly prone to chromium accumulation[Suprapti, 2008].

The content of $\mathrm{Cd}$ found in the surface water was about 0.064 and $0.1707 \mathrm{mg} \cdot \mathrm{l}^{-1}$; the highest concentration was found in the estuary of Rejo river. The concentration of $\mathrm{Cd}$ had surpassed the water quality index beingseventeen times higher. However, the concentration decreased as it went to the east. The condition did not occur in the estuary of Lohbener river. The concentration in the riverbed was about 0.055 and $0.12 \mathrm{mg} \cdot{ }^{-1}$; $\mathrm{Cd}$ was also found at the estuary of Tuntang river. The concentration surpassed the water quality index; it was 12 times greater than the index (Figure 3).

The Cd affected the fish such as Gulama Sciaena russelli living in Dumai waters. The accumulation of $\mathrm{Cd}$ was mostly found in the fins and gills. In terms of $\mathrm{Cd}, \mathrm{Cu}, \mathrm{Pb}$, and $\mathrm{Zn}$, the highest accumulation was found in the gills, since it constitutes the respiratory organ where gas exchange occurred [Nurrachmi et al., 2011].

$\mathrm{Cd}$ also correlated to green shell Perna viridis in Jakarta bay. In this area, the numbers of spermatozoa $(r=0.64)$ which influenced the development of the spermatozoon were affected to the greatest

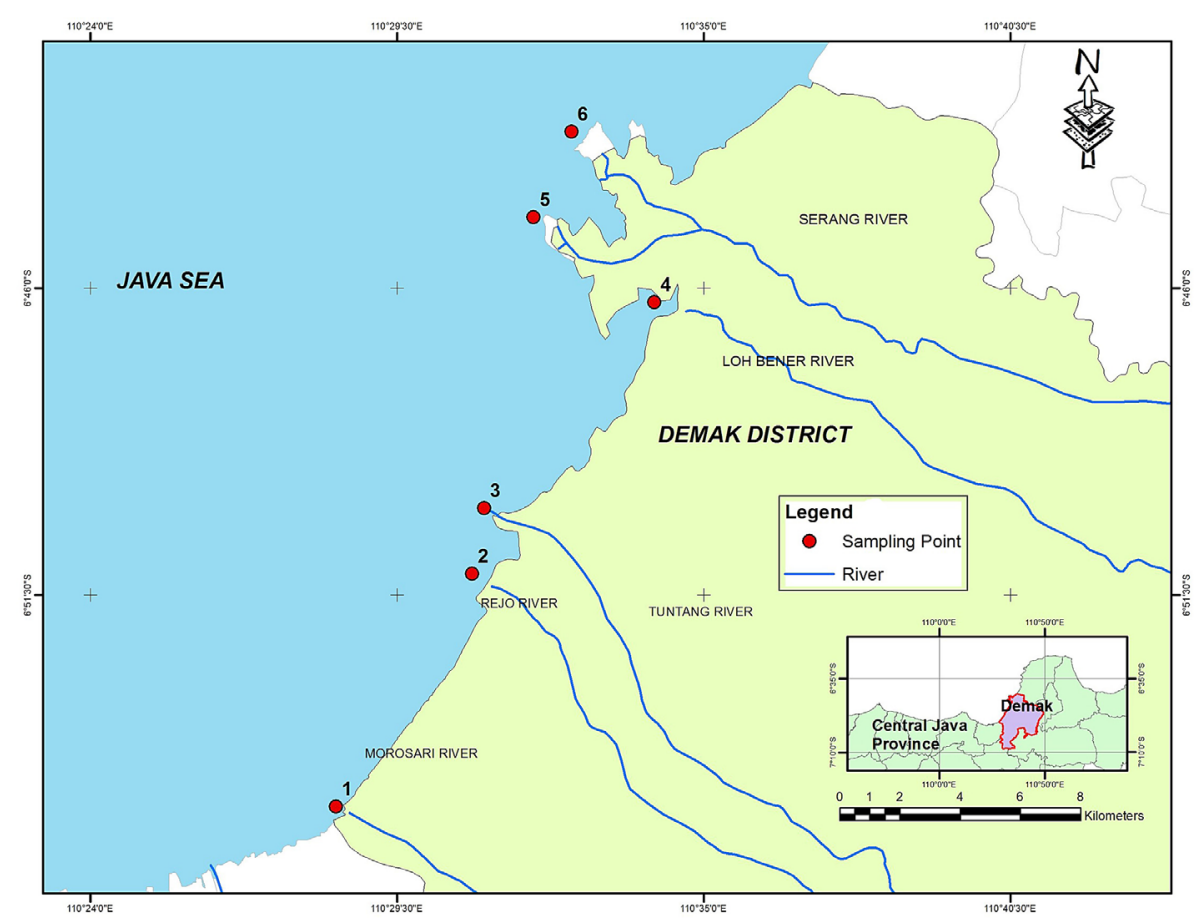

Fig. 1. Research location 


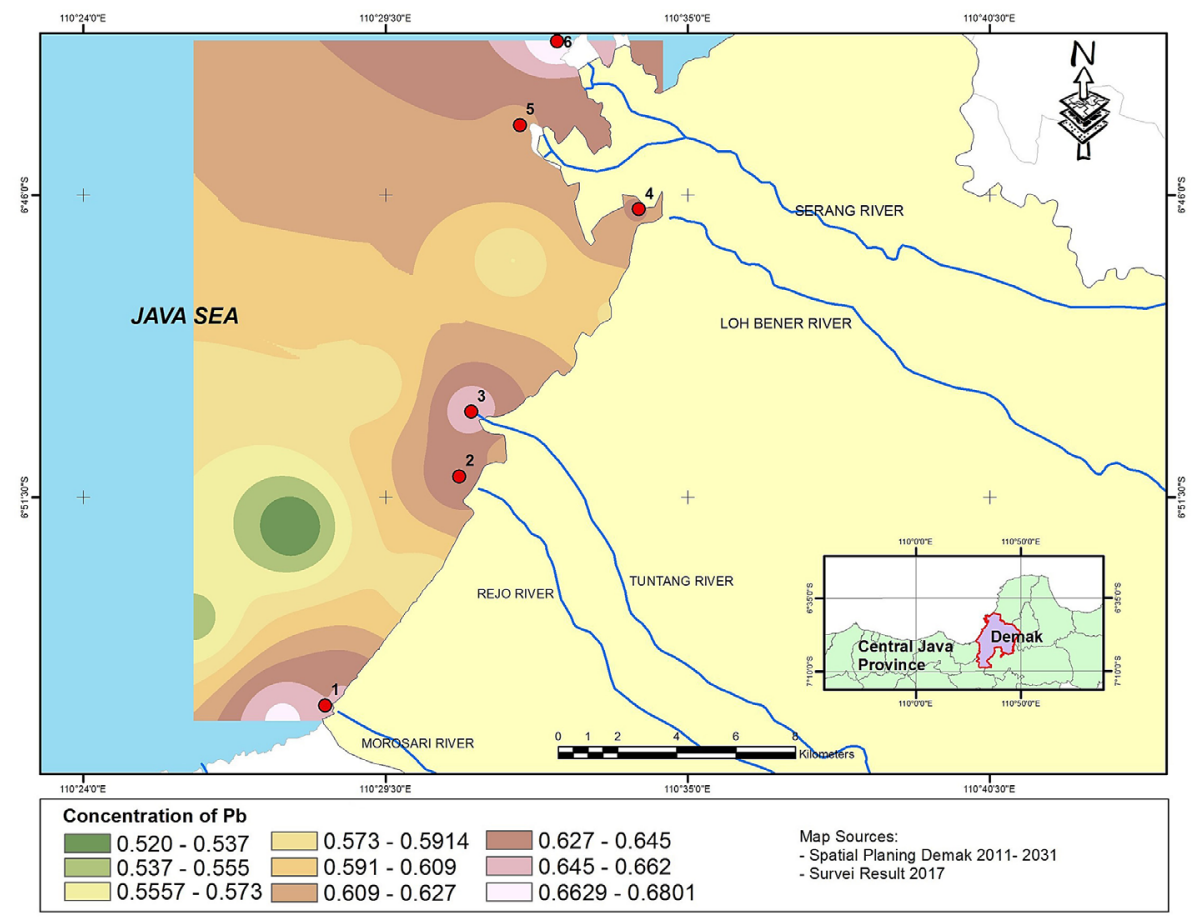

Fig. 2. The distribution of $\mathrm{Pb}\left(\mathrm{mg} \cdot \mathrm{l}^{-1}\right)$ in Demak waters

degree. It was followed by the sex cells $(\mathrm{r}=0.60)$ [Jalius et al., 2008]. Bioaccumulation also occurred in green shell Amusim pleuronectes which was found in Wedung waters, Demak the content in sediment reached $0.4694 \mathrm{mg} \cdot \mathrm{kg}^{-1}$ whereas the content on soft tissue became 12.61 times higher (5.9212 $\left.\mathrm{mg} \cdot \mathrm{kg}^{-1}\right)$ [Azhar et al., 2012].
The $\mathrm{Pb}$ content in the surface sediment ranged from 0.2563 to $0.6823 \mathrm{mg} \cdot \mathrm{kg}^{-1}$ whereas the $\mathrm{Cd}$ content ranged from 0.0047 to $0.0577 \mathrm{mg} \cdot \mathrm{kg}^{-1}$; the maximum concentration occurred in Lohbener estuary (Figure 4 and 5). The correlation between the sediment particle (sand, mud and clay) and the heavy metal $(\mathrm{Pb}$ and $\mathrm{Cd})$ showed that the

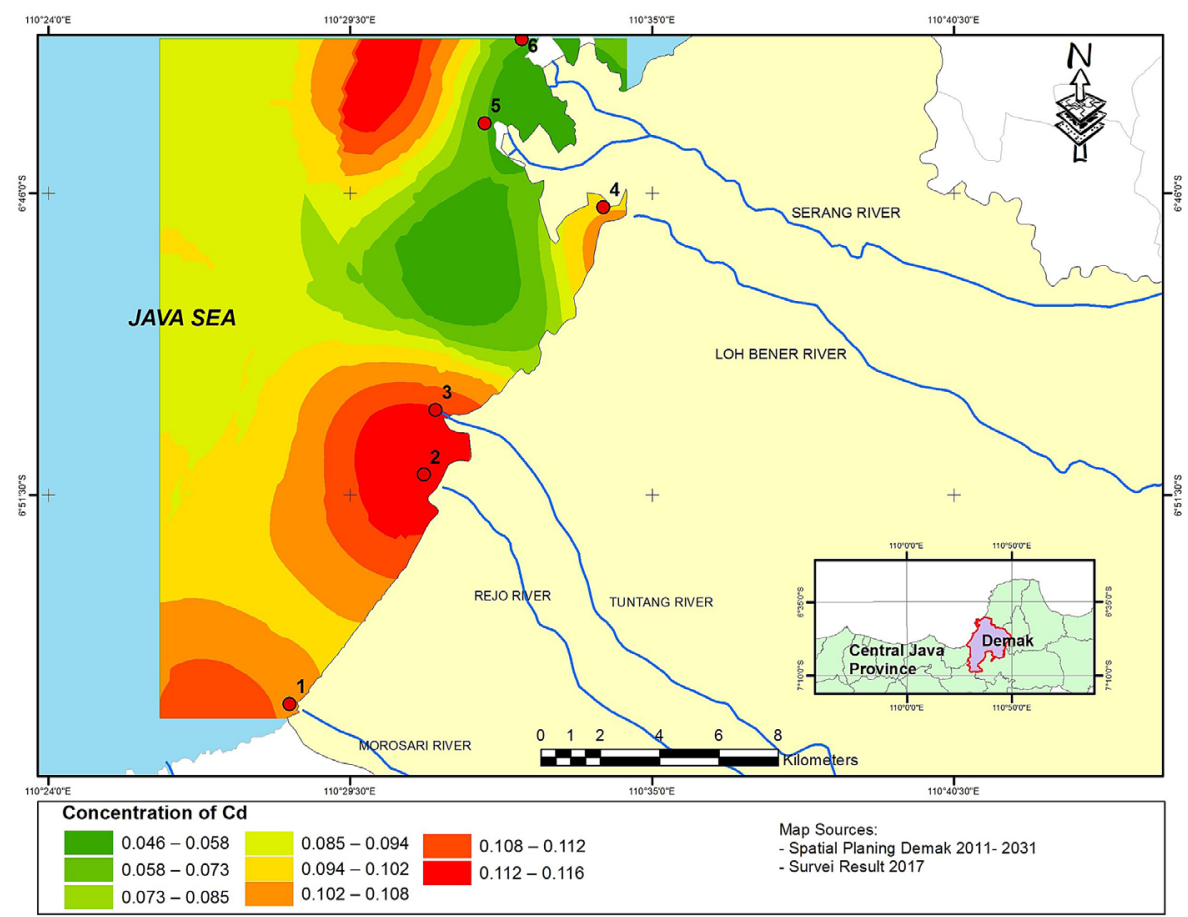

Fig. 3. The distribution of Cadmium $\left(\mathrm{mg} \cdot \mathrm{l}^{-1}\right)$ in Demak waters 
heavy metal was positively correlated with sand, mud, and clay fraction. It was found that the more mud there was, they more heavy metal $(\mathrm{Pb}$ and Cd) we found [Kinasih et al., 2015]. The content of $\mathrm{Pb}$ and $\mathrm{Cd}$ was below CEQG (Canadian Environmental Quality Guidelines) 2002 which are $30 \mathrm{mg} \cdot \mathrm{kg}^{-1}$ and $0.7 \mathrm{mg} \cdot \mathrm{kg}^{-1}$. It is in line with the guidelines of USEPA (United States Enviromental Protection Agency) (1989) which require that the $\mathrm{Pb}$ content should be below $40 \mathrm{mg} \cdot \mathrm{kg}^{-1}$. It means that according to this condition, it was regarded as not polluted.

The distribution of coliform bacteria in the six stations starting from the estuary of Morosari river to Lohbener riverhad met the quality standard, except for the station 5 Wedung and station 6 Serang, as each of them surpassing the quality standard of Coliform abundance by 400 times (Figure 6). It was influenced by the polluted ecosystem. Moreover, the household waste produced by human activities also affected the coliform abundance [Kunarso, 2011].

The analysis of the quality and condition of Demak waters included temperature, $\mathrm{pH}, \mathrm{DO}$, TDS, turbidity, salinity, current, water transparency, and depth. The water temperature of the six estuaries was about $29.08^{\circ} \mathrm{C}$ and $30.15^{\circ} \mathrm{C}$, which is common tropical water temperature. The solubility of oxygen decreased as the water temperature increased. The increase of water temperature also possibly elevated the content of some materials [Usman et al., 2013].

The $\mathrm{pH}$ ranged from 7.25 to 7.7475 which was at $\mathrm{pH}$ tolerance limit. However, the $\mathrm{pH}$ of water was quite low, below 8 , which was influenced by the river estuary. It was due to the condition of river estuary. This sea water $\mathrm{pH}$ influenced the chemical toxicity [Sindhu, 2005].

The water salinity was about 18.5 and 35.45 PSU. High salinity was found in the estuary of Morosari river. It was observed showed that the seawater's influence was greater than the fresh water, because during the high tide, the sea water flow kept moving toward the river estuary.

The oxygen solubility reached $5.06 \mathrm{mg} \cdot \mathrm{l}^{-1}$ and $6.268 \mathrm{mg} \cdot \mathrm{l}^{-1}$. The high oxygen solubility surpassed the minimum quality standard for aquaculture $\left(3 \mathrm{mg} \cdot \mathrm{l}^{-1}\right)$ [Murtini \& Peranginangin, 2006]. The solubility showed that the presence of heavy metals influenced the respiration of aquatic organism. The shortage of oxygen could possibly occur due to the increase of the nutrient supply and organic material such as fish farm waste or fertilizer run-off [Rangkuti et al., 2017].

Total Dissolved Solids (TDS) is defined as any dissolved and colloid materials which are in the form of chemical compound that are not filtrated by the filter with the diameter of 0.45 [Rao, 1992]. The content of TDS was $3.861 \mathrm{mg} \cdot 1^{-1}$ and 6.786 $\mathrm{mg} \cdot \mathrm{l}^{-1}$. The maximum TDS was found in the estu-

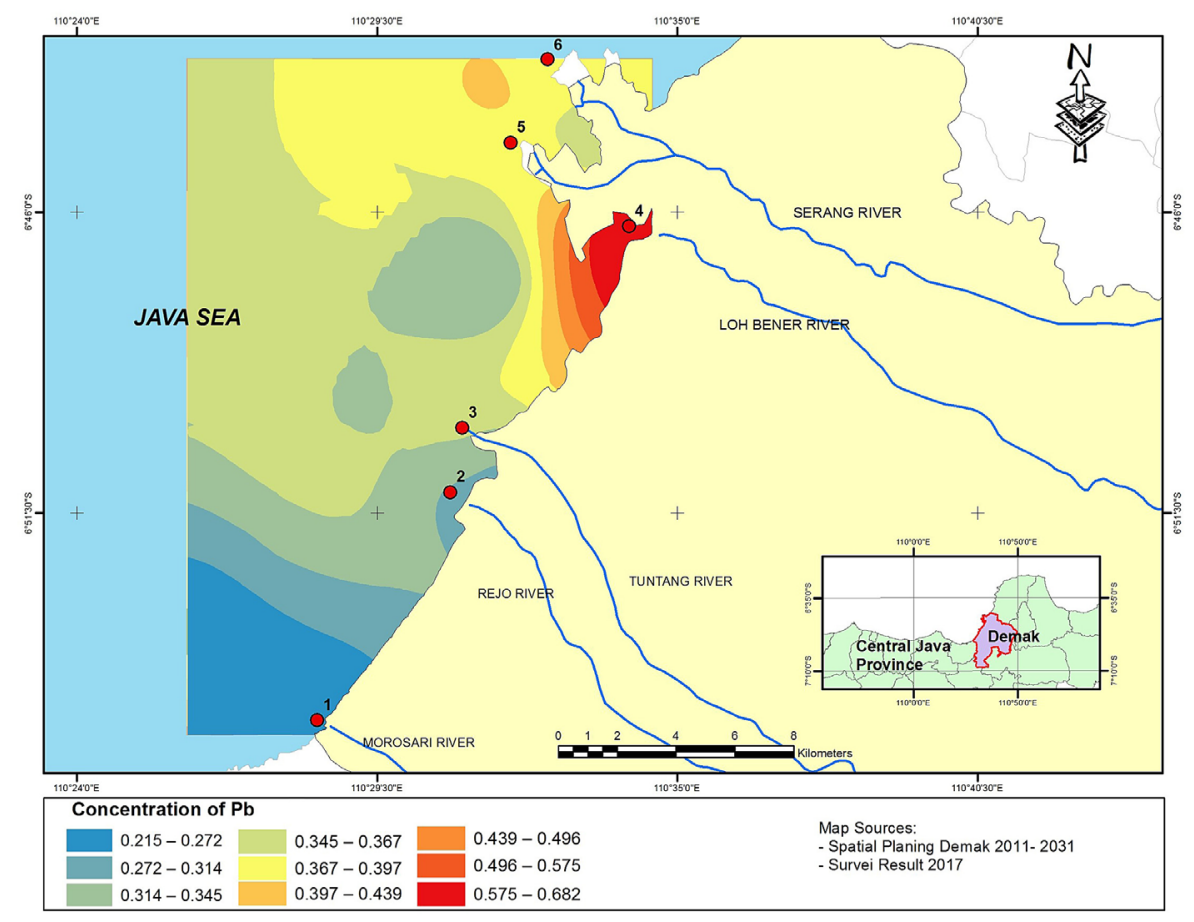

Fig. 4. $\mathrm{Pb}$ content in surface sediment $\left(\mathrm{mg} \cdot \mathrm{l}^{-1}\right)$ in Demak waters 


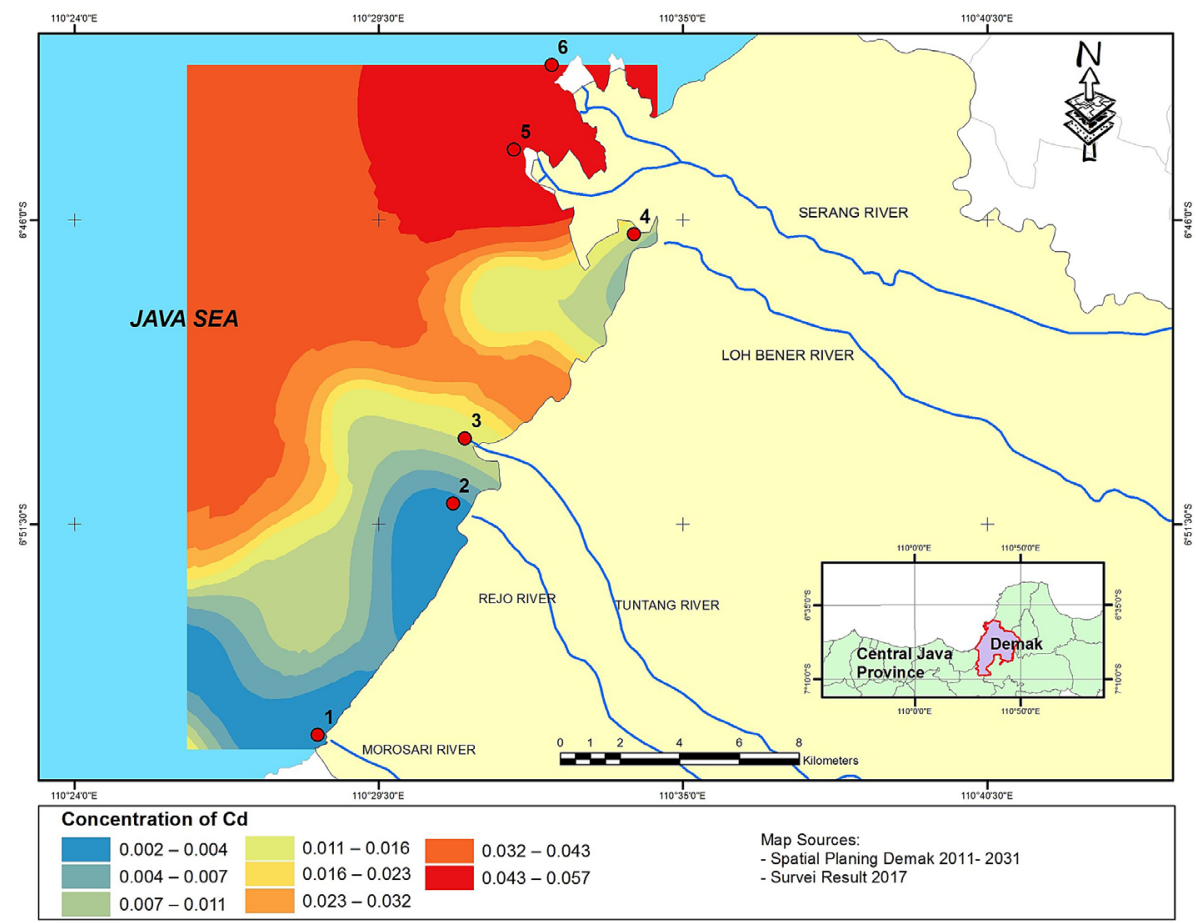

Fig. 5. Cd content in surface sediment $\left(\mathrm{mg} \cdot \mathrm{l}^{-1}\right)$ in Demak waters

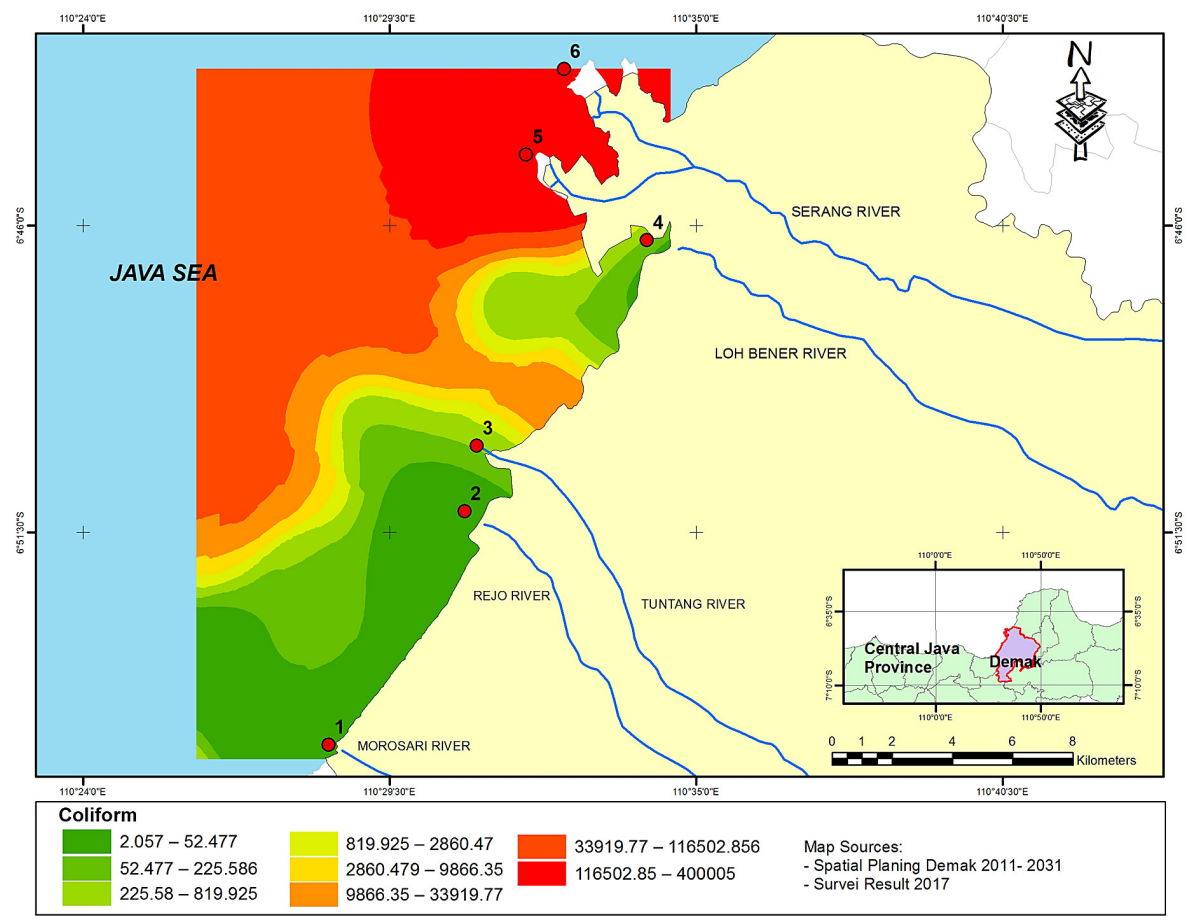

Fig. 6. Coliform abundance (MPN.-1000 ml) in Demak waters

ary of Morodemak river. The river depth ranged from 0.74 to $3.84 \mathrm{~m}$ and the water transparency was also low (Table 1).

The flow pattern during a high tide showed that the water moved to the land and the south east. When the observation took place, there was a high tide and a low tide. The highest tide oc- curred at 09:00 and the diurnal tide occurred at 19:00. This flow pattern caused the creation of the sediment and solution, despite spreading out to the sea, they gathered downstream and at the estuary (Figure 7).

On the basis of the analysis, it was revealed that $\mathrm{Pb}$ in water showed a low correlation with the 
Table 1. The quality and physical condition of Demak Waters

\begin{tabular}{|l|c|c|c|c|c|c|}
\hline Parameter/ Station & 1 & 2 & 3 & 4 & 5 & 6 \\
\hline Temperature $\left({ }^{\circ} \mathrm{C}\right)$ & $29.08 \pm 0.492$ & $29.35 \pm 0.129$ & $29.98 \pm 0.39$ & $29.95 \pm 0.351$ & $29.8 \pm 0.762$ & $30.15 \pm 0.47$ \\
\hline $\mathrm{pH}$ & $7.458 \pm 0.069$ & $7.38 \pm 0.008$ & $7.43 \pm 0.17$ & $7.25 \pm 0.087$ & $7.375 \pm 0.081$ & $7.7475 \pm 0.05$ \\
\hline DO $\left(\mathrm{mg}^{-\mathrm{I}^{-1}}\right)$ & $5.06 \pm 0.312$ & $6.268 \pm 0.102$ & $6.033 \pm 0.35$ & $5.635 \pm 0.232$ & $5.51 \pm 0.872$ & $6.2475 \pm 0.59$ \\
\hline${\text { TDS }\left(\mathrm{mg} . \mathrm{I}^{-1}\right)}^{-1}$ & $6,786 \pm 286.3$ & $4,596 \pm 398.9$ & $3,861 \pm 2,553$ & $4,240 \pm 1,991$ & $5,796 \pm 739.1$ & $5,310 \pm 308$ \\
\hline Turbidity (NTU) & $3.623 \pm 1.539$ & $1.918 \pm 0.319$ & $4.503 \pm 1.82$ & $5.035 \pm 2.413$ & $10.64 \pm 6.371$ & $32.5 \pm 4.79$ \\
\hline Salinity (ppt) & $35.45 \pm 0.129$ & $17.65 \pm 0.129$ & $19.15 \pm 0.47$ & $18.5 \pm 0.294$ & $19.1 \pm 0.52$ & $18.75 \pm 0.13$ \\
\hline Current (m.s $\left.{ }^{-1}\right)$ & 0.083 & 0.125 & 0.143 & 0.333 & 0.25 & 0.125 \\
\hline Transparency $(\mathrm{m})$ & 1.05 & 2.45 & 1.8 & 0.91 & 0.59 & 0.47 \\
\hline Depth $(\mathrm{m})$ & 2.7 & 3.84 & 2.9 & 1.7 & 0.74 & 1.2 \\
\hline
\end{tabular}

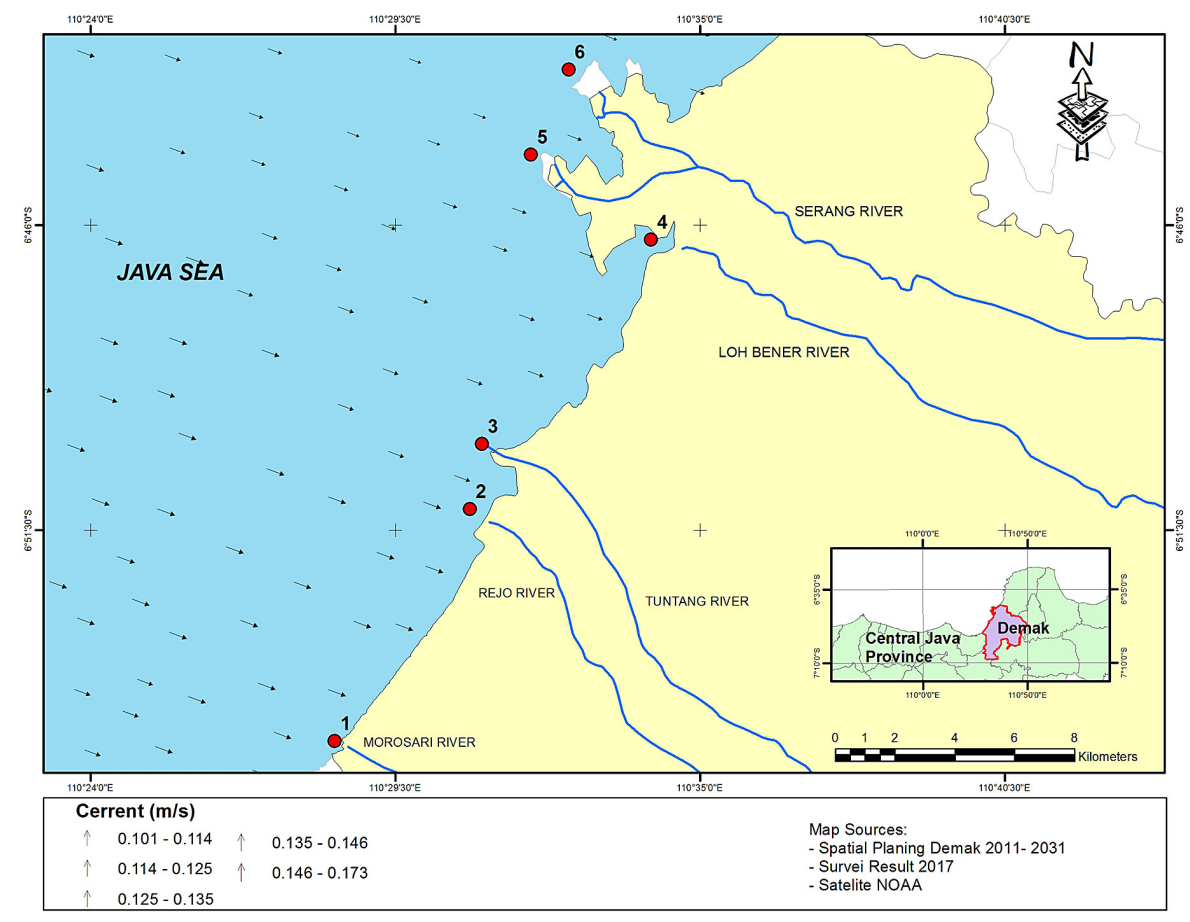

Fig. 7. Currents in Demak waters

temperature, TDS, salinity, and turbidity. Howev$\mathrm{er}, \mathrm{Pb}$ had a moderate correlation with $\mathrm{DO}$. On the other hand, $\mathrm{Cd}$ in water had a very low correlation with TDS and the turbidity. It also had a low correlation with the temperature, DO, and salinity. Moreover, it has a significant correlation to $\mathrm{pH}$. The $\mathrm{Pb}$ in sediment had a very low correlation with $\mathrm{pH}, \mathrm{DO}, \mathrm{TDS}$, salinity, and turbidity. On the other hand, it had a moderate correlation with the temperature. It was also found that the $\mathrm{Cd}$ in sediment had a very low correlation with $\mathrm{pH}, \mathrm{DO}$, TDS, salinity, and turbidity. However, the Cd in sediment was highly correlated with the temperature. Coliform was also highly correlated with the temperature but had a low correlation with $\mathrm{pH}$, TDS, and salinity. Moreover, it had a very low correlation with DO (Table 2).
The analysis revealed that the estuaries of Morosari, Rejo, Tuntang, and Lohbener were lightly polluted. However, the estuaries of Wedung and Serang were considered as heavily polluted. The pollution was caused by the abundance of coliform, which was 2400 times higher than the water quality standard of $1000 \mathrm{MPN} \cdot \mathrm{ml}^{-1}$. Moreover, the content of TDS also had surpassed the Class II water quality standard, based on Government Regulation No. 82 year 2001 about managing the quality of water and controlling water pollution. This regulation defines the requirement of water usable for fisheries. The highest content of TDS was found in the Morodemak estuary, whereas the lowest was found in the Rejo estuary (Table 3 ).

Comparing to other studies, the $\mathrm{Pb}$ content in Demak rivers was higher than what was found in 
Table 2. Spearman correlation between heavy metal and Coliform toward physicochemical variables

\begin{tabular}{|l|c|c|c|c|c|c|}
\hline & Temperature & $\mathrm{pH}$ & $\mathrm{DO}$ & TDS & Salinity & Turbidity \\
\hline $\mathrm{Pb}$ in water & -0.314 & 0.086 & 0.429 & -0.429 & -0.143 & -0.429 \\
\hline $\mathrm{Cd}$ in water & 0.257 & $0.943^{* *}$ & 0.2 & 0.143 & 0.314 & 0.143 \\
\hline $\mathrm{Pb}$ in sediment & 0.543 & -0.6 & -0.029 & -0.314 & -0.371 & -0.314 \\
\hline Cd in sediment & 0.714 & -0.371 & 0.143 & -0.371 & -0.429 & -0.371 \\
\hline Coliform & 0.771 & 0.257 & -0.029 & 0.029 & 0.2 & 0.029 \\
\hline \multicolumn{7}{|c|}{} \\
\hline
\end{tabular}

Table 3. Pollution Index Test

\begin{tabular}{|c|c|c|c|c|c|c|c|c|c|c|c|c|c|c|}
\hline \multirow{2}{*}{ No. } & \multirow{2}{*}{ Parameters } & 1 & 2 & 3 & 4 & 5 & 6 & \multirow{2}{*}{$L_{i j}$} & 1 & 2 & 3 & 4 & 5 & 6 \\
\hline & & \multicolumn{6}{|c|}{$\mathrm{C}_{\text {imax }}$} & & \multicolumn{6}{|c|}{$\mathrm{PI}_{\mathrm{i}}$} \\
\hline 1 & Turbidity & 4.96 & 2.25 & 6.09 & 7.14 & 16.14 & 36.6 & 4 & \multirow{8}{*}{3.14} & \multirow{8}{*}{2.95} & \multirow{8}{*}{2.95} & \multirow{8}{*}{2.85} & \multirow{8}{*}{145.95} & \multirow{8}{*}{146.45} \\
\hline 2 & $\mathrm{pH}$ & 7.56 & 7.39 & 7.58 & 7.33 & 7.45 & 7.8 & 7 & & & & & & \\
\hline 3 & TDS & 7050 & 4962 & 6193 & 6058 & 6472 & 5592 & 1000 & & & & & & \\
\hline 4 & DO & 5.34 & 6.36 & 6.32 & 5.82 & 6.27 & 6.81 & 6 & & & & & & \\
\hline 5 & Salinity & 35.5 & 17.9 & 19.5 & 18.9 & 20 & 18.9 & 34 & & & & & & \\
\hline 6 & $\mathrm{Cd}$ & 0.15 & 0.171 & 0.12 & 0.13 & 0.064 & 0.065 & 0.01 & & & & & & \\
\hline 7 & $\mathrm{~Pb}$ & 0.7 & 0.648 & 0.72 & 0.64 & 0.64 & 0.695 & 0.05 & & & & & & \\
\hline 8 & Coliform & 4 & 3 & 1,100 & 1,100 & $2,400,000$ & $2,400,000$ & 1,000 & & & & & & \\
\hline
\end{tabular}

some other water areas in Indonesia, such as Babon waters and estuary, port of Parepare, Katingan \& Kahayan waters, Kendari and Kelabat bay. Moreover, the $\mathrm{Pb}$ content in Demak waters was 1640 higher than the $\mathrm{Pb}$ content in Kelantan, but was equal to the one in Jinzhou bay. The content of $\mathrm{Cd}$ in Demak water was also greater than in those areas, except for Kelabat and Jinzhou bay. However, the content of $\mathrm{Pb}$ in the sediment found in Demak was lesser than in the areas above, except for Tanjung Tias waters. The $\mathrm{Cd}$ content in the sediment investigated in this research was also lower than the contents which revealed in previous studies (Table 4).

Table 4. Comparison of the current research to the previous studies

\begin{tabular}{|c|c|c|c|c|c|}
\hline \multirow[t]{2}{*}{ Waters } & \multicolumn{2}{|c|}{$\begin{array}{l}\text { Concentration in Sea Water } \\
\qquad\left(\mathrm{mg} \cdot \cdot^{-1}\right)\end{array}$} & \multicolumn{2}{|c|}{$\begin{array}{l}\text { Concentration in Surface Sediment } \\
\qquad\left(\mathrm{mg} \cdot \mathrm{kg}^{-1}\right)\end{array}$} & \multirow[t]{2}{*}{ References } \\
\hline & $\mathrm{Pb}$ & $\mathrm{Cd}$ & $\mathrm{Pb}$ & $\mathrm{Cd}$ & \\
\hline Demak estuary & $0.6506 \pm 0.0229$ & $0.0938 \pm 0.0264$ & $0.3918 \pm 0.1493$ & $0.0247 \pm 0.0202$ & Recent study \\
\hline Babon estuary & $0.02901 \pm 0.0114$ & NA & NA & NA & Kartikasari et al., 2002 \\
\hline Tangerang coastal & NA & NA & $7.822 \pm 6.2786$ & $0.1 \pm 1.4629$ & Hariyadi et al., 2017 \\
\hline Ambon island & NA & $0.01-0.03$ & NA & $0.17-0.32$ & Rumahlatu, 2011 \\
\hline Morodemak & NA & 0.011 & NA & 1.372 & Wulandari et al., 2009 \\
\hline Parepare port & $0.3468 \pm 0.2591$ & NA & $46.5199 \pm 12.4573$ & NA & Usman et al., 2013 \\
\hline $\begin{array}{l}\text { Katingan \& } \\
\text { Kahayan }\end{array}$ & $1.2942 \pm 0.1869$ & $0.0053 \pm 0.0003$ & $6.1861 \pm 1.3302$ & $0.06 \pm 0.0037$ & Harteman et al., 2008 \\
\hline Kendari bay & $0.0125 \pm 0.005$ & NA & $0.7605 \pm 0.0587$ & NA & Amriani et al., 2011 \\
\hline Betahlawang & NA & NA & $4.78-6.26$ & $2-3.1$ & Kinasih et al., 2015 \\
\hline Sayung estuary & NA & NA & $19.899 \pm 2.4741$ & NA & Amalia et al., 2014 \\
\hline Tanjung Tias & $\mathrm{BDL}$ & 0.067 & 0.126 & 0.094 & Achyani \& Salim, 2014 \\
\hline Kelabat Bay & $3.925 \pm 1.1471$ & $0.825 \pm 0.9743$ & NA & NA & Arifin, 2011 \\
\hline Tanjung Emas port & NA & NA & $10.88 \pm 3.09$ & $1.05 \pm 2.29$ & Tjahjono et al., 2017 \\
\hline Yalujiang estuary & $0.0004-0.0018$ & $0.0008-0.0013$ & $12.3-29.9$ & $0.05-0.41$ & Li et al., 2017 \\
\hline Kelantan estuary & NA & NA & $52.0133 \pm 12.1$ & $0.0733 \pm 0.0306$ & Wang et al., 2017 \\
\hline Jinzhou Bay & 0.61 & 0.92 & NA & NA & Wang et al., 2012 \\
\hline
\end{tabular}

Remarks: NA (Not Avaliable), BDL (Below Detection Limit) 


\section{CONCLUSION}

The lead content in Demak waters was higher in the riverbed than the content found on the river surface. The content of $\mathrm{Pb}$ in the river surface ranged from 0.6037 to $0.6647 \mathrm{mg} \cdot l^{-1}$ whereas the content of $\mathrm{Cd}$ in the river surface ranged from 0.064 to $0.1707 \mathrm{mg} \cdot 1^{-1}$. Both the content of $\mathrm{Pb}$ and $\mathrm{Cd}$ surpassed the water quality standard. The $\mathrm{Pb}$ content in the sediment ranged from 0.2563 to $0.6823 \mathrm{mg} \cdot \mathrm{kg}^{-1}$ whereas the $\mathrm{Cd}$ content ranged from 0.0047 to $0.0577 \mathrm{mg} \cdot \mathrm{kg}^{-1}$. Both contents found in the sediment revealed that the sediments were not polluted. The pollution index test showed that Morosari, Rejo, Tuntang and Lohbener estuaries were considered as lightly polluted, whereas Wedung and Serang estuaries were heavily polluted. Most of the $\mathrm{Pb}$ and $\mathrm{Cd}$ contents in Demak waters were higher than in the previous studies. However, the $\mathrm{Pb}$ and $\mathrm{Cd}$ content in the sediment considered in the current research was lower than what had been found in the previous studies.

\section{Acknowledgment}

First of all, the writer's deepest gratitude goes to Funding of Budget Project Instructions (DIPA) PIP Semarang year of 2017 without whom this research would never be conducted. The writer also would like to express gratitude to the team of Faculty of Fisheries and Marine Diponegoro University, especially to Vian and Andreas who had willingly helped in collecting the samples. Last but not least, to Health Laboratory Semarang which had done the measurement of heavy metal content in both seawater and sediment and coliform abundance, thank you. This research could not have been completed without your help.

\section{REFERENCES}

1. Achyani R., Gazali S. 2014. Evaluation and accumulation of heavy metals on Anadara Granosa and Anadara inaequivalvis in Tarakan waters (In Indonesian). Jurnal Harpodon Borneo, 7(1), 19-26.

2. Amalia R., Widada S., Hariyadi. 2014. Analysis of heavy metal Lead in riverbed sediment of Sayung estuary, Demak regency (In Indonesian). Jurnal Oseanografi, 3(2), 167-172.

3. Amriani, Hendrarto B., Hadiyarto A. 2011. Bioaccumulation of heavy metals Lead $(\mathrm{Pb})$ and Zinc $(\mathrm{Zn})$ in blood cockles (Anadara granosa L.) and mangrove cockles (Polymesoda bengalensis L.) in
Kendari Bay waters (In Indonesian). Jurnal Ilmu Lingkungan, 9(2), 45-50.

4. APHA (American Public Health Association). 2012. Standard methods for examination of water and waste water, 22nd edition. Street NW (US) : Water Environment Federation, pp. 1496.

5. Arifin Z. 2011. The concentration of heavy metals in water, sediment, and biota in Kelabat Bay, Bangka Island (In Indonesian). Jurnal Ilmu dan Teknologi Kelautan Tropis, 3(1), 104-114.

6. Azhar H., Widowati I., Suprijanto J. 2012. Study of the contents of heavy metal $\mathrm{Pb}, \mathrm{Cu}, \mathrm{Cd}, \mathrm{Cr}$ in simping scallop (Amusim pleuronectes), water, and sediments found in Wedung waters Demak and maximum tolerable intake analysis in humans (In Indonesian). Journal of Marine Research, 1(2), 35-44.

7. Bambang A.G., Fatimawali, Kojong N. 2014. Analysis of Coliform contamination and Escherichia coli identification in water refills of Manado city depots (In Indonesian). Universitas Sam Ratulangi, Manado. Jurnal Ilmiah Farmasi, 3(3).

8. BPS (Biro Pusat Statistik). 2013. Area of Demak regency in 2013 (In Indonesian). https://demakkab. bps.go.id, diakses 14 January 2018.

9. BPS (Biro Pusat Statistik). 2015. Fish production based on type of fresh fish sold in 2 fish auction in Demak regency 2015 (In Indonesian). https://demakkab.bps.go.id acessed January 14th 2018.

10. Effendi H. 2003. Assessment of water quality for water source and environmental management (In Indonesian). Penerbit Kanisius, Yogyakarta.

11. Hariyadi S., Muflih A., Mashar A., Widigdo B., Wardiatno Y. 2017. Spatial distribution of some heavy metals in the sediments of Tangerang coastal waters, Banten Province, Indonesia. AES Bioflux, 9(2).

12. Hartenan E., Soedharma D., Winarto A., Sanusi H.S. 2008. Detection of heavy metals in waters, sediments, and fish fins of Badukang (Arius caelatus HAN A. Maculatus) at the esturies of the Kahayan and Katingan rivers, Central Kalimantan (In Indonesian). Berita Biologi, 9(3), 275-283.

13. Hasan S. 2004. Analysis of characteristics of aquatic environment affecting on the accumulation of heavy metals Lead in the body of blood clam in the coastal waters of eastern North Sumatra (In Indonesian). Jurnal Ilmu-Ilmu Perairan dan Perikanan Indonesia, 1(1), 53-60.

14. Hastuti E.D., Anggoro S., Pribadi R. 2013. The influence of vegetation type and density on the content of $\mathrm{Cd}$ and $\mathrm{Cr}$ sediment in coastal areas of Semarang and Demak (In Indonesian). Prosiding Seminar nasional Pengelolaan Sumber daya alam dan lingkungan.

15. Heriyanto N.M., Subiandono E. 2011. Absorption of heavy metal pollutants $(\mathrm{Hg}, \mathrm{Pb}$ and $\mathrm{Cu}$ ) by mangrove species (In Indonesian). Jurnal Penelitian 
Hutan dan Konservasi Alam, 8(2), 177-188.

16. Ijong F.G. 2015. Fisheries \& marine microbiology (In Indonesian). Rineka Cipta, Jakarta.

17. Jalius, Setiyanto D.D., Sumantadinata K., Riani E., Ernawati Y. 2008. The heavy metal of accumulation and its effects to spermatogenesis on the green mussel (Perna viridis). Jurnal Ilmu-Ilmu Perairan dan Perikanan Indonesia, 15(1), 77-83.

18. Jiyah, Sudarsono B., Sukmono A. 2017. Distribution analysis of Total Suspended Solid (TSS) in coastal waters of Demak regency using LANDSAT imagery (In Indonesian). Jurnal Geodesi Undip, 6(1).

19. Kartikasari V., Tandjung S.D., Sunarto. 2002. The accumulation of heavy metals $\mathrm{Cr}$ and $\mathrm{Pb}$ on mangrove Avicennia Marina at Babon estuary the border of Semarang and Demak regency of Central Java (In Indonesian). Manusia dan Lingkungan, IX, Nov, 137-147.

20. Keputusan Menteri Negara Lingkungan Hidup Nomor 115 Tahun 2003 tentang [Guidelines on Water Quality Status Determination] [In Indonesian].

21. Keputusan Menteri Negara Lingkungan Hidup Nomor 51 Tahun 2004 tentang Water Quality Standard for Coastal water (In Indonesian).

22. Kinasih A.R.N., Purnomo P.W., Ruswahyuni. 2015. Analysis of the relationship texture sediment with organic materials, heavy metal $(\mathrm{Pb}$ and $\mathrm{Cd})$ and macrozoobenthic at Betahlawang river, Demak. Diponegoro Journal of Maquares Management of Aquatic Resources, 4(3), 99-107.

23. Kunarso D.H. 2011. The quality of waters in Makassar strait viewed from bacteriological aspect (In Indonesian). Biosfera, 28(1), 32-34.

24. Li H., Li L., Ye S., Li H., Fan J.. 2017. Assessment of nutrient and heavy metal contamination in the seawater and sediment of Yalujiang Estuary. Marine Pollution Bulletin, 117, 499-506.

25. Murtini J.T., Peranginangin R. 2006. Heavy metal contents in Asiatic Hard Clams (Meritrix meritric) and sea water in Banjarmasin (In Indonesian). Jurnal Perikanan, VIII (2), 177-184.

26. Nasution S., Siska M. 2011. The content of heavy metal lead $(\mathrm{Pb})$ in sediments and snails (Strombus canarium) in the coastal waters of Bintan island (In Indonesian). Jurnal Ilmu Lingkungan, 5(2), 82-93.

27. Nemerow N.L. \& Sumitomo H. 1970. Benefits of water quality enhancement. Report no. 16110 DAJ, prepared for the U.S. Environmental Protection Agency.

28. Nurrachmi I., Amin B., Habibi M.N. 2011. Bioacumulation of $\mathrm{Cd}, \mathrm{Cu}, \mathrm{Pb}$ and $\mathrm{Zn}$ in some parts of $\mathrm{Gu}-$ lama (Sciaena russelli) body from Dumai waters, Riau (In Indonesian). Maspari Journal, 02(01-10).

29. Palar H. 2012. Pollution and toxicology of heavy metals (In Indonesian). Rineka Cipta, Jakarta.

30. Panuntun P., Yulianto B., Ambariyanto. 2012. Ac- cumulation of heavy metal $\mathrm{Pb}$ on coral Acropora aspera: a preliminary study (In Indonesian). Journal of Marine Research, 1(1), 153-158.

31. PP (Peraturan Pemerintah) Nomor 82 Nomor 2001 about Water quality management and pollution control (In Indonesian).

32. Priyatno D. 2008. Independently learning SPSS (Statistical Product and Service Solution) for data analysis \& statistical test (In Indonesian). Mediakom, Yogyakarta.

33. Priyatno D. 2010. Easy and fast technique to perform data analysis with SPSS and question and answer on exams (In Indonesian). Penerbit Gava Media, Yogyakarta.

34. Rangkuti A.M., Cordova M.R., Rahmawati A., Yulma, Adimu H.E. 2017. Coastal and marine ecosystems of Indonesia (In Indonesian). Bumi Aksara, Jakarta.

35. Rao C.S. 1992. Environmental pollution control engineering. Wiley Eastern Limited, New Delhi, pp. 431.

36. Ridhowati S. 2013. Identifying Metal Pollution (In Indonesian). Graha Ilmu, Yogyakarta.

37. Rumahlatu D. 2011. Concentrations of heavy metals Cadmium in water, sediment and Deadema setosum (Echinodermata, Echinoidea) in the waters of Ambon island (In Indonesian). Ilmu Kelautan, Juni, 16(2), 87-85.

38. Samawi M.F., Tambaru R., Husain A.A., Burhanuddin A.A. 2014. Distribution of heavy metal Lead $(\mathrm{Pb})$ in benthic organisms and sediments of Bonebatang waters (In Indonesian). Prosiding Simposium Nasional Kelautan dan Perikanan 2014, Universitas Hasanuddin Makassar.

39. Sindhu S.F. 2005. The content of heavy metals $\mathrm{Cu}$, $\mathrm{Zn}$ and $\mathrm{Pb}$ in water, tilapia (Oreochromis niloticus) and common carp (Cyprinus carpio) in floating net cages, Saguling Reservoir (In Indonesian). Skripsi, diterbitkan Jurusan Manajemen Sumberdaya Perairan FKIP IPB, Bogor.

40. SNI (Standar Nasional Indonesia) 2897-2008. Method of microbial contamination assessment in meat, eggs, milk and dairy products (In Indonesian).

41. SNI (Standar Nasional Indonesia)-01-2332-1991. Determination of Coliform and Escherichia coli (In Indonesian).

42. Suprapti N.H. 2008. Chromium content in waters, sediments and blood clams (Anadara granosa) in coastal area around the estuary of Sayung River Morosari Village Demak Regency, Central Java (In Indonesian). BIOMA, 10(2), 36-40.

43. Tjahjono A., Bambang A.N., Anggoro S. 2017. Pollution assessment in surface sediments of trace metal in port of Tanjung Emas Semarang. Advanced Science Letters, 23, 2215-2219.

44. Triadayani A.E., Aryawati R., Diansyah G. 2010. 
The influence of metal Lead $(\mathrm{Pb})$ in humpback grouper's liver tissue (Cromileptes altivelis) (In Indonesian). Maspari Journal, 1, 42-47.

45. USEPA. 1989. Sediments classification methods compendium. Draft final report. United States Environmental Protection Agency, Watershed Protection Division, USA.

46. Usman S., Nafie N.L., Ramang M. 2013. Quantitative Distribution of heavy metals $\mathrm{Pb}$ in water, sediment and Crimson Snapper (Lutjanus erythropterus) around Parepare waters (In Indonesian). Marina Chimica Acta, 14(2).

47. Wang A-j, Bong C.W., Xu Y-h., Hassan M.H.A., Ye X., Bakar A.F.A., Li Y-h., Lai Z-k., Xu J., Loh K.H. 2017. Assessement of heavy metal pollution in surficial sediments from a tropical river-estauary-shelf system: a case study of Kelantan River, Malaysia. Marine Pollution Bulletin, http://dx.doi. org/10.1016/j.marpolbul.2017.08.010.

48. Wang J., Liu R.H., Yu P., Tang A.K., Xu L.Q., Wang J.Y. 2012. Study on the pollution characteristics of heavy metals in seawater of Jinzhou Bay. Procedia Environmental Sciences, 13, 1507-1516, doi 10.1016/j demak, accesed Januari 14th 2018.

49. Wulandari S.Y., Yualianto B., Santoso G.W., Suwartimah K. 2009. The content of heavy metals Hg and $\mathrm{Cd}$ in water, sediment and blood clam (Anadara granossa) using Neutron Activation Analysis Method (APN) (In Indonesian). Ilmu Kelautan, 14(3), 170-175. 